\title{
Exploring Malaysian University Students' Awareness of Green Computing
}

\author{
Tunku Badariah Tunku Ahmad, Abdullahi Bello and Mohamad Sahari Nordin \\ Institute of Education, International Islamic University Malaysia
}

\begin{abstract}
This study explored Malaysian university students' awareness of green computing in two aspects, i.e. vocabulary and issues, and sought to ascertain whether these two aspects were influenced by gender and field of study (ICT versus non-ICT). A total of 224 university students from ICT- and nonICT related fields participated in the survey. Students filled out a green computing questionnaire with 21 items measuring awareness of vocabulary and issues. Descriptive statistics, independent-samples t-test and Principal Components Analysis (PCA) were used to analyze the data. Results show that a majority of students lacked awareness of terms, ideas and issues central to green computing, such as E-PEAT, Energy Star, green PC, Malaysia Green Technology Policy, e-waste, and carbon-free computing. The PCA analysis extracted two factors, named Environmental Protection and Nature of Computers, that could be used to explain students' lack of familiarity with green ICT. Field of study was shown to impact awareness in all the aspects measured in favor of students educated in ICT-related fields, but the findings produced mixed gender effects. The results indicate the need for green computing education to be integrated into higher education curriculum and for university-led green initiatives to be implemented on Malaysian university campuses to increase awareness in the subject matter.
\end{abstract}

Keywords-carbon-free computing, eco-friendly computing, environmentally sustainable computing, green computing

\section{INTRODUCTION}

$\mathrm{G}$ REEN computing is fundamental to sustaining a green environment, and going green is a major concern of the modern world today. The global society as a whole is going through a phase where individuals, groups, organizations, industries and governments are becoming more environmentally conscious at home and the workplace, as well as at schools and university campuses. There is much discussion centering upon how to reduce energy consumption and carbon emissions, prevent wastage, cut costs and protect the environment through green ideas, green initiatives, green buildings and green policies. The Internet literature and

Manuscript received October 12, 2013. This work was part of a Master's thesis project in Instructional Technology.

Tunku Badariah Tunku Ahmad is Associate Professor in Instructional Technology at the Institute of Education, International Islamic University Malaysia (IIUM), 53100 Gombak, Kuala Lumpur (corresponding author; phone: 603-61965328; fax: 603-61964851; email: badariah (ium. edu.my)

Abdullahi Bello is a doctoral student in Instructional Technology at the Institute of Education, International Islamic University Malaysia (IIUM), 53100 Gombak, Kuala Lumpur (email: birchibellowyahoo.com)

Mohamad Sahari Nordin is Professor in Research and Statistics at the Institute of Education, International Islamic University Malaysia (IIUM), 53100 Gombak, Kuala Lumpur (email: msahari@itumedu.my) academic journals are awash with discussions on these issues and with solutions on how to go green, ranging from simple tips such as printing on both sides of the paper using small fonts and printing only when necessary to physical acts of greening the environment by planting more trees to offset carbon emissions to big ideas such as green buildings [1], virtualization, cloud computing, renewable energies, classified power capping [2], and intelligent computation [3]. All these efforts and attention reflect the growing importance of and the need for sustaining a healthy environment through green computing.

Green computing is often defined as the study and practice of using computing resources efficiently [4] and the environmentally responsible use of computers and their associated subsystems. This includes buying and using energy-efficient servers and peripherals, central processing units or CPUs, disposing of electronic waste (e-waste) in a safe and ethical manner, and reducing wasteful or unnecessary consumption of resources. A more inclusive conception is provided by Murugesan [5], who explains the field as "the study and practice of designing, manufacturing, using and disposing of computers, servers, and associated subsystems, such as monitors, printers, storage devices, and networking and communication systems, efficiently and effectively with minimal or no impact on the environment" (pp. 25-26). In this conception, green computing is a field that encompasses four important domains, i.e. design, manufacture and production, use and disposal of computing resources. Within this framework, the field not only embraces energy-efficient and carbon free computing (computing that reduces the impact of carbon on the environment), but it also emphasizes the nonuse of hazardous chemicals, such as cadmium, lead, chromium, mercury, selenium and brominated flame retardants (BFRs), in the manufacturing of the computer and its by-products. Figure 1 illustrates the domains of green computing as put forward by Murugesan.

Energy consumption is the central issue in green computing both from an economical and an environmental viewpoint [6]. From an economical viewpoint, concerns rise over massive amounts of money spent monthly and annually to power computer systems, servers and data centers, and to support the computing activities of end users, network providers, and system administrators. Unfortunately a large portion of these amounts is spent on wasteful and unnecessary computing.

DOI: 10.5176/2345-7163_1.2.34 
Experts estimated that USD $\$ 250$ billion per year is spent on powering computers worldwide, but only about $15 \%$ of that power is spent on real computing. The rest of the amount, constituting an estimated USD \$ 212.5 billion, is wasted on powering idle computers [7]. Most ICT users are not aware of

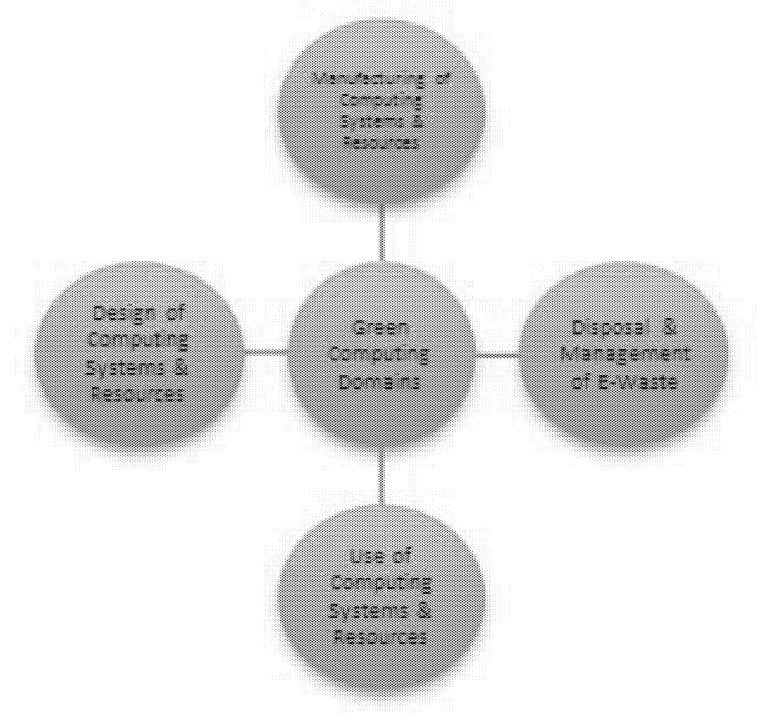

Fig. 1. The four domains of green computing (Murugesan, 2008)

this colossal wastage of money and energy. In fact, half of the world's energy wastage is caused by uninformed behaviours of end users, in addition to inefficient technologies and poorly designed systems [8].

From an environmental viewpoint, use of ICT resources and computing activities are directly associated with the release of carbon dioxide $\left(\mathrm{CO}_{2}\right)$ into the atmosphere. On the average, each $\mathrm{PC}$ in use generates about a metric ton of carbon dioxide per year [9]. Servers and data centers use up even more electricity and generate vast amounts of $\mathrm{CO}_{2}$. In 2008, the use of ICTs worldwide was responsible for an estimated $2 \%$, or 0.86 metric gigatons, of global $\mathrm{CO}_{2}$ emissions [10]. These carbon emissions, also called carbon footprint, combine with other greenhouse gases to cause increased global temperatures, smog, acid rain, droughts in some countries and floods in others. Electricity consumption by ICT users and the resulting carbon footprint are major contributors to global warming. It has been forecast that by 2020 , computing activities alone will account for $3 \%$ of all emissions, representing about 1.54 metric gigatons of greenhouse gases, while worldwide adoption of mobile phones will increase their carbon footprint by $300 \%$ [11]. If we factor in the fact that ICT infrastructure and computing power will continue to expand in capacity and reach, we might be looking at a carbon footprint of more than 3\%. Experts claim that the explosive use of ICTs is now growing at twice the speed of the Gross World Product, and is quickly surpassing the aviation industry in terms of carbon footprint [12].

But this is just one side of the environmental coin. On the other side, we have dumping of e-waste in landfills, lack of recycling programmes to handle used computer products appropriately, and use of hazardous materials in the manufacturing of ICT hardware. What many end users are not aware of is the fact that computers and their associated subsystems are manufactured using toxic chemicals, e.g. lead, cadmium, mercury and chromium. Therefore as e-waste, they are potentially harmful to the environment, the people in the environment, and vicinity areas. If left buried in landfills, they leach the toxic chemicals into the ground and waterways. If burned, they release toxic gases and poison the air that we breathe [13]. Analysts predicted that at the end of their 5-year lifecycle, around 870 million PCs produced around the world will end up in landfills in China, India and Ghana, usually in the hands of children who are tasked to reclaim components from the e-waste exported into their countries by developed economies. In 2010, the Shantou University Medical College found $88 \%$ of the 167 children tested for blood lead levels (BLLs) in Guiyu to be affected by lead poisoning. Guiyu is the "e-waste capital" of China and the children, all of whom were under 6 years of age, were either workers at the e-waste dumpsite or had parents who were working there. They developed lead poisoning from being exposed to the lead dust that emerged from the e-waste or from their parents who accumulated lead dust on their clothes from their e-waste processing jobs [14].

The overarching goal of green computing, therefore, is to address these economical and environmental hazards of computing. Its specific aims are multiple, i.e. to prevent energy waste, cut down on costs, reduce carbon emissions into the atmosphere, minimize pollution within the environment caused by poor e-waste management, curb the effects of hazardous computer products on people and the environment, and ultimately promote responsible, energy-efficient and environmentally safe computing practices. These aims render green computing part of the larger system of ethics governing the use of ICT, which university students must be aware of and adhere to, being vast users of ICT. To engage in responsible computing practices, students should have some notion of how much electricity is consumed daily by their PCs, the amount of money the university pays to support oncampus computing activities, the relationship between energy use and carbon emission, how their carbon footprint contributes to total greenhouse gas emissions and hence global warming, and how irresponsible e-waste dumping affects the health and safety of others. These are some basic green computing facts that university students should be sufficiently acquainted with.

University students depend on ICTs for a great number of things. They use online databases for research, the laptop and LCD projector for class presentations, productivity software to produce assignments and graphics, emails and social networking sites for communication, e-learning platforms for accessing class materials, networks for sharing resources, YouTube for edutainment, and printing facilities for printing stuff. Many students nowadays blog, while others tweet. Some maintain a YouTube channel, while almost every single one of them has a Facebook account. These countless computing activities mean a substantial amount of personal carbon footprint, which the average university student is most likely not aware of. In order to reduce global carbon footprint 
and its resulting effects on global temperatures, it is necessary to reduce personal carbon footprint and individual consumption of electricity. University students can play a significant role in reducing global warming, but it has to start with an awareness of green computing. Raising awareness is the first step toward the adoption of green computing behaviours and practices. By using ICT resources efficiently, students can help to reduce global $\mathrm{CO}_{2}$ emissions by about $15 \%$. This is equivalent to 7.8 billion metric tons of carbon dioxide $[15,16]$. To execute this important role as responsible and energy-efficient users of ICTs, an awareness and understanding of green computing is essential.

Given the enormous importance of energy-efficient computing in sustaining a green environment, it is paramount to know what students and other end users of ICT understand about green computing or whether they are familiar with it at all. Their awareness and understanding of what it constitutes is crucial to ensuring the success of green initiatives. Yet research efforts assessing this awareness and understanding are acutely lacking. Out of one hundred articles retrieved from the Internet and online databases on green computing, only two $[17,18]$ were found to directly examine students' awareness. A few others have looked at the attitudinal aspects of green computing adoption among students $[19,20]$. The large bulk of extant literature has focused either on theoretical perspectives explaining the value and need for green computing [21], or on myriad solutions to implementing green systems and software for the IT industry [22], IT vendors, data centers [23], and businesses [24]. Our study was prompted by the acute lack of research in green computing awareness involving end users, particularly university students who are vast consumers of ICTs. Our research was premised upon the idea that end user awareness is an important foundation of the green computing movement, a necessary precursor to knowledge development in the area and to the acquisition of the right frame of mind for environmentally sustainable computing. Ample research should be directed into exploring the levels of awareness among university students in green computing as the findings may provide useful data for drawing up green initiatives on university campuses.

\section{RESEARCH OBJECTIVES}

Set within this framework, our research objectives were as follows:

1.to explore the levels of green computing awareness among students in a public university in Malaysia by identifying whether they were familiar with its core vocabulary, and central themes and issues;

2. to uncover the underlying dimensions of students' green computing awareness through the application of Principal Components Analysis (PCA), and

3. to determine whether gender and field of study, in this case ICT-related versus non-ICT related field, had an influence on students' awareness of the vocabulary, issues and underlying dimensions.

\section{LITERATURE REVIEW}

The first green ICT initiative could be traced back to 1992 with the introduction of the Energy Star programme by the U.S. government, whose objective was to identify and label computer products that succeeded in minimizing energy consumption without losing their performance efficiency. The efforts led to the introduction of the sleep mode for computer monitors, a function that allows a monitor to go on standby and hibernate after a set period of being idle, thereby saving electricity [25]. From that point onwards, many parts of the entire computer system have been vigorously researched, experimented and improved on in a perpetual strive to create energy-efficient machines that align well with the notion of sustainable computing. Among recent additions to the now long list of green compliant computer products are NV-RAMs [26], OLED monitors, 3rd generation Intel Core processors and solid state drives [27]. Efforts to go green will push harder as the world sees increased power consumption, rising energy costs and aggravated harmful effects of computing.

On many of the world's college and university campuses today, green computing initiatives are already shaping the lives and practices of their campus populations. A number of universities in the U.S., Canada, Australia, Europe and the U.K. have for some time been creating awareness among students through green plans and sustainability campaigns. Some are very serious about energy reduction and have gone as far as erecting carbon-neutral buildings. A case in point is the University of Copenhagen (UCPH) in Denmark which in 2009 successfully built an energy-efficient center for its student services. The building is completely carbon free and powered by a combination of solar energy, heating pumps and a district heating. On top of a carbon-neutral building, UCPH has a Green Action plan in which it employs green ambassadors to promote good energy conservation habits among students and staff. The plan helped UCPH to reduce its energy consumption and carbon footprint by $2.5 \%$ in 2012 . On a lesser scale, the University of Utah in Salt Lake City, U.S. maintains a sustainability website that educates its students and staff on the ways to reduce paper and electronic waste. It has a green policy that provides guidelines on ewaste management and hardware retirement. It also implements free e-waste collections and provides a calendar specifying dates on which e-waste will be collected. In Australia, green computing is offered as an online course by the Australian National University and the University of New South Wales as part of an effort to increase awareness in environmentally sustainable computing, in line with propositions that green computing education be integrated into tertiary curriculum [28]. The universities' move to offer the course completely online is also an act compliant with environmentally sustainable computing as e-learning options are hailed as a viable way of reducing energy consumption and $\mathrm{CO}_{2}$ emissions by a substantial percentage [29].

Research in green computing is vast and multi-faceted. The green computing literature is replete with propositions, plans, campaigns, initiatives, and hardware and software solutions, but it is extremely limited in looking at an important group of people at the receiving end who makes a huge difference in 
reducing global energy consumption through their computing activities - students. Research in the area has almost overlooked the importance and role of students as agents of $\mathrm{CO}_{2}$ reduction. Students are vast users of ICTs, and hence, vast contributors of carbon emission. By creating an awareness of green computing and getting them to act in green compliant ways, we would be able to cut down a huge portion of the $2 \%$ carbon footprint attributable to computing activities. But our literature search produced only two studies that provided some insight into the state of green computing awareness among students in higher education settings. The first [30] assessed Botswanan students' awareness of green ICT vocabulary, i.e. terms associated with green computing, and the compliance of their computing practices with sustainable computing. The author found that the majority of students had limited or no knowledge of green computing issues, and frequently engaged in practices that led to unnecessary high consumption of electricity. Although the college made efforts to create energy conservation awareness via posting green ICT messages and power saving tips in all classes and computer labs, students' levels of green computing awareness remained low and discouraging. Despite the efforts, students remained oblivious to the need to use energy efficiently. The author concluded that green computing knowledge and education was lacking at the college, and extensive work needed to be done to sensitize its campus population on going green.

The second study [31] found slightly higher levels of awareness among Mauritian students, but discovered a gap between their awareness levels and practices. Although students reported having moderate knowledge and awareness of green computing, their daily practices were inconsistent with their self-report. Only $18 \%$ turned off their computers when not in use, and most had misconceptions about power saving practices, for instance in thinking that screen savers save energy. The authors emphasized the importance of university-led initiatives in increasing students' awareness, recommending a sustainability website to be put in place and the implementation of a green technology policy. In both studies, students were reported as heavy users of computers and the Internet with high degrees of computer literacy. In a U.S. study, Seitz et al. [32] discovered students' attitudes toward green computing and their intention to adopt it to be significantly influenced by awareness. The respondents demonstrated positively compliant behaviors following initiatives that increased their awareness of green computing.

\section{METHODOLOGY}

\section{A. Measurement of Awareness}

Awareness is the state of being conscious of ideas or events [33] or the state of realizing that something exists [34]. A person becomes aware of an idea or event as a result of having heard of it or having come into contact with it through various different means, such as through conversations, discussions, watching commercials, reading leaflets, listening to the news, and others. In this study, awareness of green computing was defined as students' familiarity with the notion as a result of having heard about it from whatever sources. The construct was measured in two ways, i.e. awareness of its vocabulary and awareness of its issues. Vocabulary awareness was assessed by getting students to indicate their familiarity with eight green computing terms and ideas on a dichotomous scale, that is by asking them to state whether they had heard or not heard of the words. Awareness of issues was assessed through students' self-rating of thirteen (13) statements concerning the impact of computers on the environment, energy consumption, e-waste and its management, and hazardous materials used in computer manufacturing. Students were asked to rate the levels of their awareness on the issues on a 5-point Likert scale.

\section{B. Sample}

The respondents were 224 university students randomly and purposively sampled from nine faculties of a public university in Malaysia. About 43\% were studying in ICT-related fields, such as Computer Engineering, Computer-Aided Design, Computer Science and Software Engineering, and the remaining $57 \%$ in non-ICT related specializations, such as Political Science, Economics and Management, Religion, Education and English Language. Slightly over half were male (54\%), while $46 \%$ were female. All of the students were digitally literate with a computer experience of between 10 and 20 years. The sample was drawn using a combination of random and purposive sampling techniques. A criterion was set for choosing ICT respondents in that they must be students pursuing studies in ICT-related areas. These students were identified from two main faculties, Engineering and Information and Communications Technology (ICT), and purposively sampled using this criterion. Non-ICT respondents were randomly selected from all other faculties not offering academic programmes specifically related to ICT.

\section{C.Instrument}

The instrument used to collect data was a self-developed green computing questionnaire with three sections. Section A requested details regarding respondents' demographic information, such as gender, field of study (ICT-related or non-ICT related), faculty and years of computer experience. Section B contained eight (8) dichotomous items that measured awareness of green computing vocabulary. The items simply asked whether respondents had heard or not heard of the following terms and ideas: "green computing", "green PC", "carbon footprint", "carbon-free computing", "ewaste", "Energy Star", "E-PEAT", and "Malaysia Green Technology Policy." The response required was a simple "Yes" or "No". Section C contained thirteen (13) items requiring a self-report. Respondents were asked to rate the degree of their familiarity with matters related to energy use, impact of computers on the environment, green certification programmes, characteristics of a PC, e-waste and disposal of old hardware. Respondents were required to rate the level of their awareness on a 5-point Likert scale ranging from "High", "Quite High", "Moderate", "Low" to "Zero."

The items were generated from an extensive review of literature on green computing. They went through two rounds of validation, first for green ICT content by ICT experts, and 
second for psychometric properties by measurement experts. They were then pilot tested on a representative sample of the target respondents. Refinements were made to the items following feedback from the pilot test. The reliability of the data based on Kuder-Richardson formula 21 was $\mathrm{KR}_{21}=0.90$ for the 8 dichotomous items, and Cronbach's alpha $\alpha=0.92$ for the 13 Likert-type items. The PCA-extracted underlying dimensions showed alpha values of .92 for Environmental Protection and .77 for Nature of Computers. These indices constitute a very good indicator of data and instrument reliability for a social science research $[35,36]$.

\section{D.Data Collection and Analysis}

The questionnaires were administered personally by hand, via e-mail and in class with the help of lecturers. Some respondents were given a few days to respond; others filled them out on the spot. A number of follow-up measures, i.e. email reminders, text messages and phone calls, were used to ensure a high response rate. In total, 300 questionnaires were sent out, and 224 usable ones were returned, constituting a response rate of about $75 \%$.

The data were analyzed using a combination of descriptive and inferential techniques. Responses to the eight dichotomous items measuring awareness of green computing vocabulary were given a score of 1 for "Yes" and " 0 " for "No." The scores were summated and displayed in frequency counts and percentages to show the distribution of students with and without awareness of the vocabulary. This was first done for all respondents to show general levels of awareness, and then by gender and field of study to show differences. The summated scores were subjected to two independent samples t-test analyses to ascertain the influence of gender and field of study on students' awareness levels.

Responses to the thirteen Likert-type self-report items on green computing issues were first analyzed using simple frequency counts and percentages. In a subsequent analysis using independent-samples $t$-test, scores from the student ratings were summated and tested for statistically significant differences attributable to gender and field of study. The level of statistical significance adopted for the analysis was $\mathrm{p}<$ 0.05 , which formed the basis of whether or not a statistically significant difference existed between the groups under study.

In the final analysis, data from the thirteen Likert-type items were subjected to a Principal Components Analysis (PCA) procedure with orthogonal Varimax rotation to identify the underlying dimensions that influenced the variability of students' green computing awareness. Based on the dimensions extracted, summated scores were computed and subjected to independent samples t-tests to check for influences of gender and field of study.

\section{V.RESULTS}

\section{A.Awareness of Green Computing Vocabulary}

Figure 2 shows the percentage distribution of students who were familiar and not familiar with the eight green computing vocabulary items in question. Interestingly, half of the students $(\mathrm{n}=112)$ had not heard of the term "green computing", while $54 \%$ had not heard of green PC. The remaining items saw huge majorities not having heard of them before. Almost consistently across the board, there were more students who had not come across the terms than those who had. The most striking are the percentages of students who were not familiar with E-PEAT (77\%), Malaysia Green Technology Policy (67\%), carbon-free computing (64\%), ewaste $(63 \%)$, and Energy Star $(61 \%)$. The results indicate that an overwhelming number of university students in the public university at the time of the survey were not aware of many terms and ideas central to green computing.

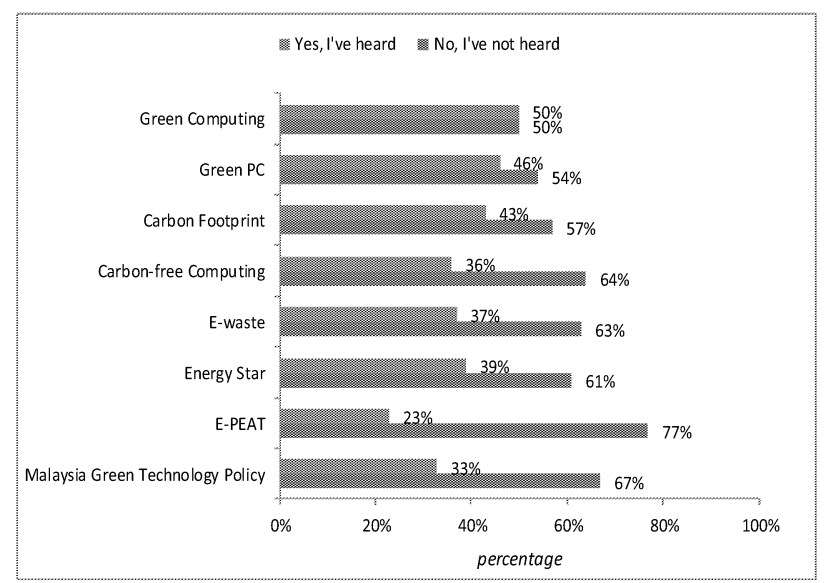

Fig. 2. Percentage distribution of university students who were familiar and not familiar with the eight green computing vocabulary items asked $(\mathrm{N}=224)$

Figure 3 shows the gender breakdown of students who indicated familiarity with the items. These were students who had responded "Yes" to having heard of the terms.

The results reveal that there were more female students who

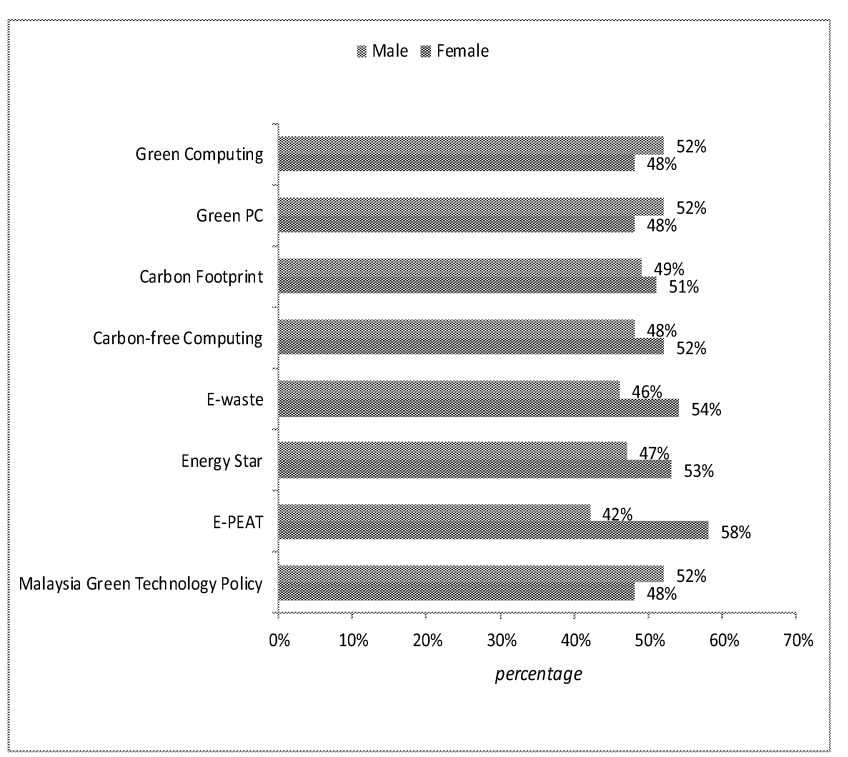

Fig. 3. Gender distribution of university students familiar with the eight green computing vocabulary items asked $(\mathrm{N}=224)$ 
were familiar with the green ICT vocabulary than there were male students. Females outnumbered males on five items, i.e. carbon footprint, carbon-free computing, e-waste, Energy Star and E-PEAT, while males outnumbered females on three items, i.e. green computing, green PC and Malaysia Green Technology Policy.

In general, gender differences on these items appear marginal, ranging between 2 percentage points (on carbon footprint) and 8 percentage points (on e-waste). An exception was the item E-PEAT where a substantially greater number of females were familiar with it than males. On this item, females outnumbered males by 16 percentage points. At face value, it appears that female students tend to have awareness of terms more highly specialized in nature, like E-PEAT, Energy Star and e-waste. In contrast, male awareness of green computing vocabulary tend to center around more general terms.

Figure 4 shows the percentage breakdown of students who indicated familiarity with the eight vocabulary awareness items by field of study.

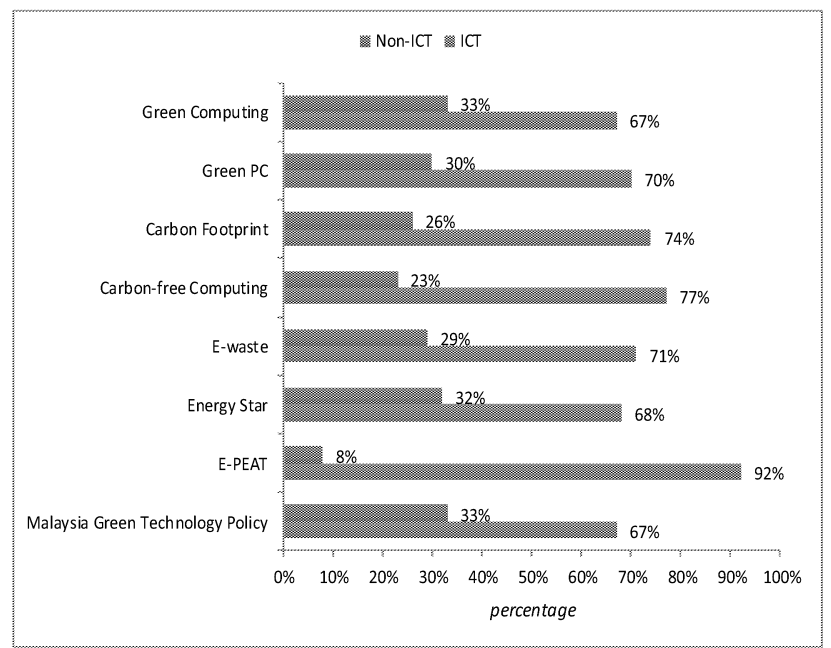

Fig. 4. Percentage breakdown of university students who indicated familiarity with the eight green computing terms by field of study (ICT vs non-ICT)

Consistently across the board, ICT-based students substantially outnumbered non-ICT students on every item asked. The differences in percentages ranged from a minimum of 34 points (on the items green computing and Malaysia Green Technology Policy) to a maximum of 84 points (on EPEAT). The item that showed up to be familiar to the least number of students was E-PEAT, and of those who reported familiarity with E-PEAT, only $8 \%$ constituted non-ICT students. Across all items, non-ICT student representations made up one-third or less of those familiar with the ideas in question. And for all items, ICT students more than doubled the number of non-ICT students in terms of awareness.

\section{B. Awareness of Green Computing Vocabulary: The Influence of Gender and Field of Study}

The next step in the analysis illustrates the influence of field of study and gender on students' green computing vocabulary
TABLE I

INFLUENCE OF GENDER AND FIELD OF STUDY ON STUDENTS' AWARENESS OF GREEN COMPUTING VOCABULARY: A SUMMARY OF INDEPENDENT SAMPLES

\begin{tabular}{lcccccc}
\multicolumn{7}{c}{ T-TEST RESULTS $(\mathrm{N}=223)$} \\
\hline \hline Respondents & $\mathrm{n}$ & $\mathrm{df}$ & $\mathrm{M}$ & $\mathrm{SD}$ & $\mathrm{t}$ & $\mathrm{p}$-value \\
\hline Gender & & & & & & \\
- Male & 120 & 221 & 2.81 & 2.86 & -1.415 & $0.159^{*}$ \\
- Female & 103 & & 3.38 & 3.16 & & \\
Field & & & & & & \\
- ICT & 96 & 221 & 5.13 & 2.96 & 10.999 & $0.001 * *$ \\
- Non-ICT & 127 & & 1.52 & 1.92 & & \\
\hline \hline
\end{tabular}

*not significant at $p>0.05 ; * *$ significant at $p<0.05$

awareness. This was established by computing the students' total scores on the eight items and running two independentsamples $t$-tests on the summated scores by gender and field of study. The results are presented in Table 1.

The $t$-test results on the groups' mean scores show that gender did not influence students' green computing vocabulary awareness, [ $\mathrm{t}(221)=-1.415, \mathrm{p}=0.159]$, although female students did demonstrate a slightly higher mean score on the scale $(\mathrm{M}=3.38, \mathrm{SD}=3.16)$. On the other hand, field of study shows a statistically significant impact on awareness; $\mathrm{t}(221)=10.999, \mathrm{p}=0.001$, in favor of the group pursuing ICT-related

studies. ICT-based students obtained a much higher score on the scale $(\mathrm{M}=5.13, \mathrm{SD}=2.96)$ than did non-ICT students, suggesting the influence of their ICT-related education on green computing vocabulary awareness. The gap between the groups accounted for a 45-percentage point difference, with a standardized effect size of Cohen's $d=1.20$. This means that the effect size was practically large, and that the difference between the means of the two groups was larger than one standard deviation.

\section{C.Awareness of Green Computing Issues}

Table 2 presents the distribution of students' rating of their awareness levels on the thirteen (13) green computing issues. Student responses across the five levels of awareness were retained as they were and not collapsed so as to give a clear picture of how the students viewed their awareness of green computing issues. Quite apparently, most of the students rated themselves as having either low levels of awareness or none of it at all on a majority of the green computing issues. An exception can be made to three issues in question, i.e. the impact of computers on the environment, the amount of electricity used by a single computer, and the energy-saving features of a PC or laptop, of which only about $12 \%, 19 \%$ and $25 \%$ respectively reported having low levels and no awareness at all. Students' awareness ratings on these three issues were higher compared to their ratings on the rest of the items. The remaining ten items had between $32 \%$ (on whether used computer equipment should be recycled) and $64 \%$ (on e-waste management in Malaysia) of students reporting having no awareness or low levels of awareness. The lowest rating was found for Malaysia's e-waste management act $(\mathrm{M}=1.16$, SD $=1.12$ ), followed by e-waste management in Malaysia $(\mathrm{M}=$ $1.19, \mathrm{SD}=1.18)$, EPEAT-registered computer products being 
TABLE 2

SUMmaRy OF STUDENTS' RATING OF THEIR AWARENESS LEVELS OF GREEN COMPUTING ISSUES

\begin{tabular}{|c|c|c|c|c|c|c|c|}
\hline \multirow{2}{*}{ Item } & \multicolumn{5}{|c|}{ Reported Level of Awareness (\%) } & \multirow{2}{*}{ M } & \multirow{2}{*}{ SD } \\
\hline & High & Quite High & Moderate & Low & Zero & & \\
\hline Impact of computers on the environment & $\begin{array}{c}37 \\
(16.5)\end{array}$ & $\begin{array}{c}64 \\
(28.6)\end{array}$ & $\begin{array}{c}96 \\
(42.9)\end{array}$ & $\begin{array}{c}23 \\
(10.3)\end{array}$ & $\begin{array}{c}4 \\
(1.8)\end{array}$ & 2.48 & 0.95 \\
\hline Amount of electricity used by a computer & $\begin{array}{c}29 \\
(12.9)\end{array}$ & $\begin{array}{c}62 \\
(27.7)\end{array}$ & $\begin{array}{c}90 \\
(40.2)\end{array}$ & $\begin{array}{c}33 \\
(14.7)\end{array}$ & $\begin{array}{c}10 \\
(4.5)\end{array}$ & 2.30 & 1.02 \\
\hline $\begin{array}{l}\text { Hazardous chemicals are used in } \\
\text { manufacturing computers }\end{array}$ & $\begin{array}{c}18 \\
(8.0)\end{array}$ & $\begin{array}{c}64 \\
(28.6)\end{array}$ & $\begin{array}{c}60 \\
(26.8)\end{array}$ & $\begin{array}{c}61 \\
(27.2)\end{array}$ & $\begin{array}{l}21 \\
(9.4)\end{array}$ & 1.99 & 1.12 \\
\hline How old ICT hardware should be disposed of & $\begin{array}{c}11 \\
(4.9)\end{array}$ & $\begin{array}{c}33 \\
(14.7)\end{array}$ & $\begin{array}{c}81 \\
(36.2)\end{array}$ & $\begin{array}{c}67 \\
(29.9)\end{array}$ & $\begin{array}{c}32 \\
(14.3)\end{array}$ & 1.66 & 1.05 \\
\hline $\begin{array}{l}\text { What the energy saving features of a } \\
\text { PC/laptop are }\end{array}$ & $\begin{array}{c}20 \\
(8.9)\end{array}$ & $\begin{array}{c}62 \\
(27.7)\end{array}$ & $\begin{array}{c}85 \\
(37.9)\end{array}$ & $\begin{array}{c}38 \\
(17.0)\end{array}$ & $\begin{array}{c}19 \\
(8.5)\end{array}$ & 2.12 & 1.07 \\
\hline $\begin{array}{l}\text { Where used ICT hardware should be disposed } \\
\text { of }\end{array}$ & $\begin{array}{c}13 \\
(5.8)\end{array}$ & $\begin{array}{c}34 \\
(15.2)\end{array}$ & $\begin{array}{c}62 \\
(27.7)\end{array}$ & $\begin{array}{c}70 \\
(31.3)\end{array}$ & $\begin{array}{c}45 \\
(20.1)\end{array}$ & 1.55 & 1.14 \\
\hline $\begin{array}{l}\text { Organizations in Malaysia that take care of e- } \\
\text { waste }\end{array}$ & $\begin{array}{l}15 \\
(6.7)\end{array}$ & $\begin{array}{c}25 \\
(11.2)\end{array}$ & $\begin{array}{c}54 \\
(24.1)\end{array}$ & $\begin{array}{c}73 \\
(32.6)\end{array}$ & $\begin{array}{c}57 \\
(25.4)\end{array}$ & 1.41 & 1.18 \\
\hline E-waste management in Malaysia & $\begin{array}{c}13 \\
(5.8)\end{array}$ & $\begin{array}{c}19 \\
(8.5)\end{array}$ & $\begin{array}{c}47 \\
(21.0)\end{array}$ & $\begin{array}{c}64 \\
(28.6)\end{array}$ & $\begin{array}{c}81 \\
(36.2)\end{array}$ & 1.19 & 1.18 \\
\hline $\begin{array}{l}\text { Used computer products can be } \\
\text { remanufactured }\end{array}$ & $\begin{array}{c}21 \\
(9.4)\end{array}$ & $\begin{array}{c}42 \\
(18.8)\end{array}$ & $\begin{array}{c}80 \\
(35.7)\end{array}$ & $\begin{array}{c}49 \\
(21.9)\end{array}$ & $\begin{array}{c}32 \\
(14.3)\end{array}$ & 1.87 & 1.16 \\
\hline $\begin{array}{l}\text { EPEAT-registered computer products are } \\
\text { environmentally friendly }\end{array}$ & $\begin{array}{c}12 \\
(5.4)\end{array}$ & $\begin{array}{c}19 \\
(8.5)\end{array}$ & $\begin{array}{c}60 \\
(26.8)\end{array}$ & $\begin{array}{c}54 \\
(24.1)\end{array}$ & $\begin{array}{c}79 \\
(35.3)\end{array}$ & 1.25 & 1.18 \\
\hline Computer equipment should be recycled & $\begin{array}{c}22 \\
(9.8)\end{array}$ & $\begin{array}{c}55 \\
(24.6)\end{array}$ & $\begin{array}{c}75 \\
(33.5)\end{array}$ & $\begin{array}{c}48 \\
(21.4)\end{array}$ & $\begin{array}{c}24 \\
(10.7)\end{array}$ & 2.01 & 1.13 \\
\hline Malaysia's e-waste management act & $\begin{array}{c}9 \\
(4.0)\end{array}$ & $\begin{array}{c}17 \\
(7.6)\end{array}$ & $\begin{array}{c}56 \\
(25.0)\end{array}$ & $\begin{array}{c}60 \\
(26.8)\end{array}$ & $\begin{array}{c}82 \\
(36.6)\end{array}$ & 1.16 & 1.12 \\
\hline $\begin{array}{l}\text { Malaysia's computer hardware recycling } \\
\text { programmes }\end{array}$ & $\begin{array}{c}11 \\
(4.9)\end{array}$ & $\begin{array}{c}20 \\
(8.9)\end{array}$ & $\begin{array}{c}58 \\
(25.9)\end{array}$ & $\begin{array}{c}68 \\
(30.4)\end{array}$ & $\begin{array}{c}67 \\
(29.9)\end{array}$ & 1.29 & 1.13 \\
\hline
\end{tabular}

environmentally friendly $(\mathrm{M}=1.25, \quad \mathrm{SD}=1.18)$, and Malaysia's computer hardware recycling programmes $(\mathrm{M}=$ $1.29, \mathrm{SD}=1.13)$.

An intriguing finding emerged from the figures; issues on ewaste act and management, disposal and recycling of old hardware, and E-PEAT certification saw the least number of students having acceptable levels of awareness of. These were green computing aspects that students appeared least familiar with. Another prominent pattern was the percentage of students reporting moderate levels of awareness. Between $21 \%$ and $43 \%$ reported having moderate awareness even though on "tough" issues like E-PEAT, e-waste management, and e-waste

act. A close inspection of responses in the "moderate" category revealed higher percentages of them coming mostly from male students and partially from the non-ICT group. This could reflect a situation where students felt urged to give socially desirable answers [37] and report an awareness level

TABLE 3

INFLUENCE OF GENDER AND FIELD OF STUDY ON STUDENTS' AWARENESS OF GREEN COMPUTING ISSUES: A SUMMARY OF INDEPENDENT SAMPLES T-TEST

\begin{tabular}{lcccccc}
\multicolumn{7}{c}{ RESULTS $(\mathrm{N}=224)$} \\
\hline \hline Respondents & $\mathrm{n}$ & $\mathrm{df}$ & $\mathrm{M}$ & $\mathrm{SD}$ & $\mathrm{t}$ & $p$-value \\
\hline Gender & & & & & & \\
- Male & 120 & 222 & 20.69 & 9.43 & -2.487 & $0.014^{*}$ \\
- Female & 104 & & 24.09 & 10.99 & & \\
Field & & & & & & \\
- ICT & 97 & 222 & 25.01 & 10.32 & 3.571 & $0.001^{* *}$ \\
- Non-ICT & 127 & & 20.17 & 0.83 & & \\
\hline \hline
\end{tabular}

*not significant at $\mathrm{p}>0.05 ; * *$ significant at $\mathrm{p}<0.05$ higher than the actual case, hence overrating themselves on the scale. If this assumption was true, we could be looking at a greater number of Malaysian university students with less awareness of the green computing issues, with more male and non-ICT students in the equation.

\section{Awareness of Green Computing Issues: The Influence of Gender and Field of Study}

Two independent-samples t-tests run on the reported levels of awareness show significant influences of gender and field of study in favor of females and ICT-based students (Table 3).

On the average, female students reported higher levels of awareness $(M=24.09, S D=10.99)$ than did their male counterparts $(\mathrm{M}=20.69, \mathrm{SD}=9.43)$. The difference in the mean scores was found to be statistically significant, $(\mathrm{t}(222)=$ $-2.487, p=0.014$ ), with an effect size of $d=33$. And as expected, ICT-based students demonstrated higher degrees of awareness $[\mathrm{t}(222)=3.571, \mathrm{p}=0.001]$, suggesting a strong influence of ICT-related field of study on their green computing awareness at Cohen's effect size of $d=.47$

\section{E. Underlying Dimensions of Green Computing Awareness}

The PCA procedures applied on the data produced acceptable results in terms of sampling adequacy and correlations among items. The Kaiser-Meyer-Olkin (KMO) measure of sampling adequacy was 0.911 , indicating that the sample size was adequate for the application of PCA on the 
data. According to Kaiser [38] any value exceeding 0.8 is considered meritorious in terms of sampling adequacy. The Bartlett's test of sphericity was statistically significant ( $\square 2$ $=1802.677,78, \mathrm{p}=0.001)$, indicating that the overall correlations within the correlation matrix were significant. Except for two items, the communalities of the variables were acceptable at above 0.5 .

The first run of PCA produced a two-factor structure for awareness of green computing which accounted for $63.3 \%$ of the variance, but two items were found problematic as they loaded significantly on both of the factors. The two items, where used ICT hardware should be disposed of (with loadings of .629 and .404 respectively on the two factors) and how old ICT hardware should be disposed of (with factor loadings of .546 and .566 respectively) were subsequently dropped in the second run of PCA to produce more defensible results. The close similarity in how these two items were phrased could have been the cause of this problem.

As expected, the revised PCA produced better results with an improved total variance explained. The Kaiser-MeyerOlkin (KMO) measure of sampling adequacy was 0.894 . The Bartlett's test of sphericity was statistically significant ( $\square 2$ $=1452.912,55, \mathrm{p}=0.001)$, indicating overall significant correlations among items with communalities ranging between produced an eigenvalue of 5.625, and as a construct, demonstrated a very high Cronbach's alpha coefficient of .92. It alone accounted for more than half of the variance explained, which means that $51.1 \%$ of students' green computing awareness was explained by this Environmental Protection factor. Factor 2, named Nature of Computers, is represented by four items dealing with how much energy a computer uses, features within in that help save energy, hazardous materials contained within it, and its impact on the environment. The second factor, with an eigenvalue of 1.537 and a Cronbach's alpha coefficient of .77, explained approximately $13.97 \%$ of students' green computing awareness.

\section{F. Underlying Dimensions of Green Computing Awareness: The Influence of Gender and Field of Study}

Two independent-samples t-tests were run on the underlying dimensions to check for possible influences of gender and field of study. The results are shown in Table 6. On both dimensions, females and ICT students demonstrated consistently higher mean scores. Gender exerted an influence on students' awareness of the first dimension, Environmental Protection $[\mathrm{t}(222)=-2.782, \mathrm{p}=.006]$, in favor of females $(\mathrm{M}$ $=11.47, \mathrm{SD}=6.76)$, but not on the second dimension, Nature

TABLE 4

FACTOR SOLUTION WITH ITEMS, FACTOR LOADINGS, EIGENVALUES, VARIANCE EXPLAINED AND RELIABILITY INDEX

\begin{tabular}{|c|c|c|c|c|}
\hline Factor and Items & $\begin{array}{l}\text { Factor } \\
\text { Loading }\end{array}$ & Eigenvalue & $\begin{array}{l}\text { Total Variance } \\
\text { Explained }\end{array}$ & $\begin{array}{c}\text { Cronbach's } \\
\text { Alpha }\end{array}$ \\
\hline Factor 1:Environmental Protection & & 5.625 & 65.11 & .916 \\
\hline 1. Malaysia's computer hardware recycling programmes & .866 & & & \\
\hline 2. Malaysia's e-waste management act & .863 & & & \\
\hline 3. Organizations in Malaysia that take care of e-waste & .841 & & & \\
\hline 4. E-waste management in Malaysia & .839 & & & \\
\hline 5. EPEAT-registered computer products are environmentally friendly & .818 & & & \\
\hline 6. Used computer products can be remanufactured & .630 & & & \\
\hline 7. Computer equipment should be recycled & .591 & & & \\
\hline Factor 2: Nature of Computers & & 1.537 & & .774 \\
\hline 1. Amount of electricity used by a computer & .844 & & & \\
\hline 2. Impact of computers on the environment & .739 & & & \\
\hline 3. The hazardous chemicals used in manufacturing computers & .738 & & & \\
\hline 4. Energy-saving features of a PC/laptop & .633 & & & \\
\hline
\end{tabular}

.484 and .798 (Appendix A). Nine items had a communality greater than 0.5 , which suggested that at least one-half of the variance could be explained for each item by the factor solution. The remaining two items had a communality that very closely approached .5 .

The Varimax rotation extracted a clean two-factor solution without any item that cross-loaded. The solution was represented by eleven items and explained approximately $65.1 \%$ of students' green computing awareness. The two factors are shown in Table 4 along with their representative items, factor loadings, eigenvalues, variance explained and internal consistency index.

Factor 1 is named Environmental Protection and represented by seven items dealing with awareness of e-waste management and organizations, disposal of old hardware, EPEAT products, and recycling programmes. The factor of Computers, [t(222) $=-.814, \mathrm{p}=.416]$. Field of study influenced the awareness scores on both dimensions, and both times in favor of ICT students. The effect sizes (ES) for gender and field of study across the two dimensions are shown in Table 5 .

\section{DISCUSSION}

Our research has shown that an overwhelming number of Malaysian university students were not familiar with many terms, ideas and issues central to green computing. Most reported having no or limited familiarity with the vocabulary items and issues in question. Issues regarding e-waste management and disposal, local e-waste act and recycling programmes, and E-PEAT certification were particularly unfamiliar to a great number of students. Most were also unfamiliar with Energy Star and Malaysia Green Technology 
TABLE 5

INFLUENCE OF GENDER AND FIELD OF STUdy ON THE UNDERLyING DIMENSIONS OF STUDENTS' GREEN COMPUTING AWARENESS: A SUMMARY OF INDEPENDENT SAMPLES T-TEST RESULTS $(\mathrm{N}=224)$

\begin{tabular}{|c|c|c|c|c|c|c|c|c|}
\hline Dimension & Respondents & $\mathrm{N}$ & $\mathrm{df}$ & M & SD & $t$ & $p$-value & ES \\
\hline $\begin{array}{l}\text { Environmental } \\
\text { Protection }\end{array}$ & $\begin{array}{l}\text { Gender } \\
\text { - Male } \\
\text { - Female }\end{array}$ & $\begin{array}{l}120 \\
104\end{array}$ & 222 & $\begin{array}{c}9.05 \\
11.47\end{array}$ & $\begin{array}{l}6.26 \\
6.76\end{array}$ & -2.782 & $.006 *$ & .24 \\
\hline & $\begin{array}{l}\text { Field of Study } \\
\text { - ICT } \\
\text { - Non-ICT }\end{array}$ & $\begin{array}{c}97 \\
127\end{array}$ & 222 & $\begin{array}{c}11.89 \\
8.87\end{array}$ & $\begin{array}{l}6.87 \\
6.08\end{array}$ & 3.481 & $.001 *$ & .29 \\
\hline $\begin{array}{l}\text { Nature of } \\
\text { Computers }\end{array}$ & $\begin{array}{l}\text { Gender } \\
\text { - Male } \\
\text { - Female }\end{array}$ & $\begin{array}{l}120 \\
104\end{array}$ & 222 & $\begin{array}{l}8.717 \\
9.067\end{array}$ & $\begin{array}{l}2.97 \\
3.48\end{array}$ & -.814 & $.416^{* *}$ & .13 \\
\hline & $\begin{array}{l}\text { Field of Study } \\
\text { - ICT } \\
\text { - Non-ICT }\end{array}$ & $\begin{array}{c}97 \\
127\end{array}$ & 222 & $\begin{array}{l}9.485 \\
8.417\end{array}$ & $\begin{array}{l}3.01 \\
3.29\end{array}$ & 2.492 & $0.013^{*}$ & .34 \\
\hline
\end{tabular}

Policy despite the fact that the policy was introduced back in 2009 by the Prime Minister of Malaysia himself. A large percentage of students with a lack of awareness came from the group pursuing non-ICT related fields of study. We believe the number of university students ignorant and unaware of green computing to be greater than what the figures suggested, given the substantial percentages reporting moderate levels of awareness. Our findings corroborate the results of previous research $[39,40]$ that university students are generally illinformed about and oblivious to green computing issues affecting the world and the environment.

From the PCA results, two underlying factors were extracted that were useful in explaining students' green computing awareness, or rather, their lack of it. The analysis had reduced the data and pinpointed the lack of awareness down to two factors, i.e. Environmental Protection and Nature of Computers. What this means is the university students surveyed in the study generally lacked familiarity with the environmental protection aspect of computer use, and they also lacked an awareness of the nature of the machine they used on a daily basis. In other words, their use of computers was generally uninformed in terms of energy conservation and environmental impact, and they had little idea of the what, the how and the where of e-waste disposal and management that function to preserve and sustain a green environment. What was discovered in the findings has partly been observed in their practices in and around the campus. Many student habits are non-compliant with green computing, as can be in classrooms, student residentials, and computer labs. For example, printing one-sided using large fonts, leaving computers idle for hours, leaving the LCD projector on after presentations, and buying new systems when the old ones can simply be upgraded. Overadoption of ICT gadgets is also an issue, where many are taken into buying devices they do not really need just to keep up-to-date with recent advancements.

Our findings have also revealed mixed gender effects on the three green computing aspects in comparison, i.e. vocabulary, issues and underlying dmensions, but a clear positive indication of the influence of field of study on students' awareness in the three aspects. In terms of gender differences, more female students on the average showed familiarity with the items and issues posed in the questionnaire, a pattern that is consistent with observations that women are more ecoaware and eco-friendly than men [41]. However, statistically significant gender differences were only detected for the green computing issues and one of the underlying dimensions (Environmental Protection), but not for the vocabulary part and the second dimension (Nature of Computers). More research needs to be done in the area to further ascertain the extent of gender influence on awareness and other facets of green computing. On the other hand, field of study clearly had an influence on the construct, producing consistently significant findings on students' awareness of both green computing vocabulary and issues. Students without an ICTrelated education demonstrated significantly lower levels of awareness, especially in relation to ideas highly specific to green computing, like E-PEAT, carbon footprint and carbonfree computing. The results suggest a strong likelihood that green computing awareness is a function of proper, and perhaps formal, ICT-basededucation in the area.

\section{CONCLUSION}

Based on the findings and given the paramount importance of environmentally sustainable computing, we support propositions to include green computing as part of the core curriculum in higher education [42, 43]. As end users, students need to be well-informed and well aware of how to use computers and other technologies in ways that have little or no negative impact on themselves, the university where they study, the people around them, and the environment. This awareness and knowledge must be well-embedded in students through a relevant green ICT curriculum, as well as through conscious and organized university-led efforts. Universities can initiate simple yet effective awareness campaigns by putting up posters around the campus, posting messages in classrooms, lecture halls and labs, having a green ICT onestop center for questions, queries and e-waste collection services, and organizing informal talks. The mainstream media can contribute significantly to the efforts by airing short, informative commercials and running headlines of 
green computing facts and issues. Most students do not have the capability to create green ICT technologies, i.e. green hardware and software for environmental sustainability, but they do have the capability to use ICT technologies in green ways given the proper education and support. Even one student can make a difference, but it has to start somewhere. It is high time that Malaysia caught up with the rest of the world in green computing and environmental sustainability efforts on her university campuses.

\section{REFERENCES}

[1] A.M. Omer, "Green energies and the environment," Renewable and Sustainable Energy Reviews, vol. 12, pp. 1789-1821, 2008.

[2] Z. Wu, C. Giles, and J. Wang, "Classified power capping by network distribution trees for green computing," Cluster Computing, vol. 16, no. 1, pp. 17-26, 2013

[3] M. Sheikhalishahi, and L. Grandinetti. (2012, November). "Green computing: a dual technology for cloud computing and hpc," Computing Now. [Online]. Available: http//www computer.org/nortal web/computingnow/software $\% 20$ engineering/content? $g=53198$ type=a ricle\&urTitle=green-computing; -awdual-technology-for -cloud. computing and hoc

[4] J. Lamb, The greening of IT: how companies can make a difference for the environment. Boston, MA: Pearson, 2009

[5] S. Murugesan, "Harnessing green IT: principles and practices," IEEE IT Professional, vol. 10, no.1, pp. 24-33, 2008

[6] M. Lang, A. Harris, D. Yates, and S. Kruck, "Incorporating ethics and social responsibility in information systems education," Journal of Information Systems Education, vol. 22, no. 3, pp. 183-189, 2011.

[7] S. Aggarwal, M. Garg, and P. Kumar, "Green computing is smart computing: a survey," International Journal of Emerging Technology and Advanced Engineering, vol. 2, no. 2, pp. 297-303, 2012. [Online]. Available: htp//www ijetae.com/Illes/Volume2Issue2/IJETAE 0212 51 .pdf

[8] T.A. Jenkin, J. Webster, and L. McShane, "An agenda for green information technology and systems research," Information and Organization, vol. 21, pp. 17-40, 2011.

[9] Murugesan, 2008.

[10] G. Boccaletti, M. Löffler, and J.M., Oppenheim, "How IT can cut carbon emissions," McKinsey Quarterly, 2008, October. [Online]. Available: htp:/Www mckinseyquarterly.com/How IT can cut carbon emissions 2221 .

[11] Boccaletti et al., 2008.

[12] Jenkin et al., 2011.

[13] Murugesan, 2008.

[14] The China Daily $\left(2011\right.$, November $\left.16^{\text {th }}\right)$. Lead levels in children linked to rise in e-waste profits. [Online]. Available: http:/www.chinadaily.com.cn/cndy/201111/16/content 14101761 htm.

[15] Boccaletti et al., 2008

[16] B.W. Cramer, "Man's need or man's greed: the human rights ramifications of green ICTs," Telematics and Informatics, vol. 29, no. 4, pp. 337-347, 2012.

[17] B. Batlegang, "Green computing: students, campus computing and the environment: a case for botswana," Journal of Information Systems and Communication, vol. 3, no. 1, pp. 256-260, 2012.

[18] K. Dookhitram, J. Narsoo, M.S. Sunhaloo, A. Sukhoo, and M. Soobron, (2012). Green computing: an awareness survey among university of technology mauritius students, [Online]. Available: hitp:/tec.intnet.mu/pd\% 20 downloads/confpaper/confpaper091224.pdf.

[19] V. Seitz, F. Yanti, and Y. Karant, "Attitudes toward green computing in the US: can they change?" Scientific Annals of the "Alexandru Ioan Cuza" University of Iasi, Economic Sciences Section (SAAIC), 2011SE, pp. $151-158, \quad 2011 . \quad$ [Online]. Available: hitp//anale.feaa.uaic.ro/anale/resurse/201 1 semm3seitzv.pdi.

[20] S. Wing, and Y.C. Chow, "Intended belief and actual behavior in green computing in hong kong," Journal of Computer Information Systems, vol. 50, no. 2, pp. 136-142, 2009 .

[21] D.C. Chou, and A.Y. Chou, "Awareness of green IT and its value model," Computer Standards and Interfaces, vol. 34, no. 5, pp. 447-451, 2012 .
[22] S. Naumann, M. Dick, E. Kern, and T. Johann, "The greensoft model: a reference model for green and sustainable software and its engineering," Sustainable Computing: Informatics and Systems, vol. 1, no. 4, pp. 294304, 2011.

[23] M. Uddin, and A.A. Rahman, "Energy efficiency and low carbon enabler green IT framework for data centers considering green metrics," Renewable and Sustainable Energy Reviews, vol. 16, no. 6, pp. 40784094, 2012.

[24] Jenkin et al., 2011

[25] R.K. Jena, "Green computing: need of the hour," Communications in Computer and Information Science, vol. 112, pp. 312-318, 2010.

[26] T. Kawahara, and C. Yoshimura, "Low power processing with NVRAM." In Takayuki Kawahara \& Hiroyuki Mizuno (Eds.), Green Computing with Emerging Memory: Low-Power Computation for Social Innovation (pp 183-206). C. (2013). New York: Springer.

[27] C. Johnston, "Ask ars: are "green" hard drives really all that green?" Ars Technica: Gear and Gadgets, Product News and Reviews, 2011, February. [Online]. Available: hitp//arstechnica.com/gadgets/2011/01/ ask-ars-are-green-drives-really-that-green/.

[28] Lang et al., 2011.

[29] D. Akaslan, and E.L.C. Law, "E-learning in the science of electricity in higher education in turkey in terms of environment and energy," Proceedings of Postgraduate Research Student Conference 2010: Perspectives in Society, 2010. Nottingham, UK. [Online]. Available: http//www cs.le.ac uk/people/dall2/pubs/3.pdf

[30] Batlegang, 2012.

[31] Dookhitram et al., 2012.

[32] Seitz et al., 2011.

[33] K.W. Brown, and R.M. Ryan, "The benefits of being present: mindfulness and its role in psychological well-being," Journal of Personality and Social Psychology, vol. 84, pp. 822-848, 2003.

[34] F. O'Collins, The little book of awareness: an idea about an idea. Australia: UCADIA Books, 2004.

[35] N. Golafshani, "Understanding reliability and validity in qualitative research," Qualitative Report, vol. 8, no. 4, pp. 597-607, 2003.

[36] J. Kirk, and M. Miller, Reliability and Validity in Qualitative Research Methods. London, U.K: SAGE University Press, 1986.

[37] S.I. Donaldson, and E.J. Grant-Vallone, "Understanding self-report bias in organizational behavior research," Journal of Business and Psychology, vol. 17, no. 2, pp. 245-260, 2002.

[38] H.F. Kaiser, "An index of factorial simplicity," Psychometrika, vol. 39, pp. 31-36, 1974

[39] Batlegang, 2012

[40] Dookhitram et al., 2012.

[41] C. Morgenstern, "Is the green jobs movement leaving women behind?" The Green Economy Post. 2010. [Online]. Available: httr//greeneconomypostcom/green-jobs-women-8669, htm.

[42] Lang et al., 2011.

[43] P. Sendall, L.Y. Shannon, A. Peslak, and B. Saulnier, "The greening of the information systems curriculum," Information Systems Education Journal, vol. 9, no. 5, pp. 27-45, 2011. 
APPENDIX A

INTER-ITEM CORRELATION MATRIX AND COMMUNALITIES

\begin{tabular}{|c|c|c|c|c|c|c|c|c|c|c|c|c|}
\hline \multirow{2}{*}{ Item } & \multicolumn{11}{|c|}{ Item } & \multirow{2}{*}{ Communality } \\
\hline & 1 & 2 & 3 & 4 & 5 & 6 & 7 & 8 & 9 & 10 & 11 & \\
\hline 1 & 1.000 & & & & & & & & & & & .560 \\
\hline 2 & .512 & 1.000 & & & & & & & & & & .727 \\
\hline 3 & .436 & .624 & 1.000 & & & & & & & & & .630 \\
\hline 4 & .327 & .444 & .433 & 1.000 & & & & & & & & .490 \\
\hline 5 & .250 & .275 & .351 & .356 & 1.000 & & & & & & & .735 \\
\hline 6 & .246 & .302 & .427 & .327 & .745 & 1.000 & & & & & & .737 \\
\hline 7 & .318 & .295 & .368 & .405 & .503 & .505 & 1.000 & & & & & .522 \\
\hline 8 & .268 & .294 & .416 & .317 & .633 & .718 & .490 & 1.000 & & & & .707 \\
\hline 9 & .278 & .292 & .314 & .507 & .524 & .385 & .609 & .454 & 1.000 & & & .484 \\
\hline 10 & .216 & .288 & .439 & .315 & .691 & .739 & .491 & .753 & .452 & 1.000 & & .771 \\
\hline 11 & .311 & .276 & .381 & .382 & .730 & .692 & .610 & .684 & .612 & .762 & 1.000 & .798 \\
\hline
\end{tabular}

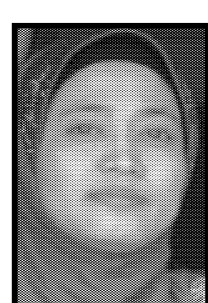

Tunku Badariah Tunku Ahmad is an Associate Professor at the Institute of Education, International Islamic University Malaysia (IIUM), Kuala Lumpur. She teaches a number of courses in instructional technology, education, and research methods. She has a bachelor's degree in English (Canada), a master's degree in Social Foundations (U.S.A) and an Ed.D in Instructional Technology and Mutimedia (Malaysia).

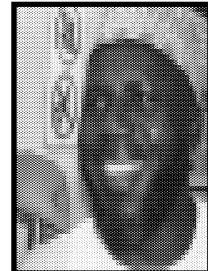

Abdullahi Bello is currently a $\mathrm{PhD}$ candidate at the Institute of Education, IIUM, majoring in Instructional Technology. He earned his master's degree at the same institute. He is Nigerian by nationality and teaches at the Katsina Polytechnic in Nigeria.

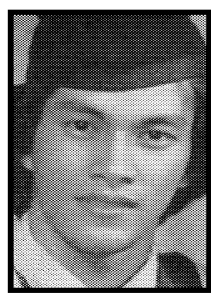

Mohamad Sahari Nordin is a Professor of Educational Measurement and Statistics at the Institute of Education, IIUM. He also teaches a wide variety of courses in Research Methods, Structural Equation Modeling, Assessment and Educational Psychology. 